\section{Pengaruh Etos Kerja, Motivasi Kerja, Kepuasan Kerja, dan Kompensasi terhadap Kinerja Polisi Biddokkes Polda Kalimantan Selatan}

\author{
Imam Hidayat ${ }^{1 *}$ dan Titien Agustina ${ }^{2}$ \\ ${ }^{1}$ Universitas Merdeka Malang \\ ${ }^{2}$ Sekolah Tinggi Ilmu Manajemen Indonesia (STIMI) Banjarmasin \\ *E-mail : himam2632@gmail.com \\ E-mail : titienagustina9@gmail.com
}

\begin{abstract}
Abstrak. Polisi Biddokkes Polda Kalimantan Selatan selalu meningkatkan kinerja kerjanya. Kinerja dipengaruhi oleh etos kerja, motivasi, kepuasan kerja, dan kompensasi. Untuk menganalisis dan mengetahui pengaruh variabel-variabel tersebut terhadap kinerja perlu dilakukan penelitian di kepolisian Biddokkes Polda Kalsel. Metode kuantitatif digunakan dalam penelitian ini. Populasinya adalah semua anggota polisi yaitu 63 orang. Teknik pengambilan sampel adalah sensus. Sampel penelitian ini 63 orang. Teknik pengumpulan data adalah kuesioner. Data dianalisis dengan analisis regresi linier. Hasil penelitian ini menunjukkan bahwa etos kerja, motivasi, kepuasan kerja, dan kompensasi berpengaruh signifikan terhadap kinerja secara parsial dan bersama-sama. Etos kerja, motivasi, kepuasan kerja, dan kompensasi perlu ditingkatkan karena variabelvariabel ini memiliki pengaruh yang signifikan terhadap kinerja.
\end{abstract}

Kata kunci: Kompensasi, Motivasi, Etos kerja, Kepuasan kerja

\begin{abstract}
Police Biddokkes Polda South Kalimantan always improves work performance. The Performance is influenced by work ethos, motivation, work satisfaction, and compensation. To analyzing and to know the influence of those variables to the performance need the research in Biddokkes Polda Kalsel. Quantitative method is used in the research. The population is all members of the police namely 63 persons. Technique of sampling is census. This research sample 63 person. The data collection technique is questioner. Data is analyzed by linier regression analysis. The results of this research shows that work ethos, motivation, work satisfaction, and compensation have influence significantly to the performance partially and together. Work ethos, motivation, work satisfaction, and compensation are need to improve because these variables have influence significantly to the performance.
\end{abstract}

Keywords: Compensation, Motivation, Work ethos, Work satisfaction

\section{Pendahuluan}

Sumber daya manusia harus dikelola dengan baik. Pengelolaan organisasi pada dasarnya adalah proses pengelolaan manusia. Semua organisasi, apapun jenisnya, ukurannya, fungsinya ataupun tujuannya memerlukan sumber daya manusia yang baik. Dibandingkan dengan elemen-elemen yang lain, manusia adalah merupakan elemen yang paling dinamis dan kompleks. Seringkali efisiensi pelaksanaan suatu organisasi tergantung pada pengelolaan dan pendayagunaan manusianya. Itulah sebabnya maka setiap manajer atau pimpinan harus mampu bekerja secara efektif dengan manusia dan harus mampu memecahkan bermacammacam persoalan sehubungan dengan pengelolaan sumber daya manusia tersebut.

Pengelolaan sumber daya manusia di dalam organisasi inilah yang dikenal sebagai manajemen sumber daya manusia. Kinerja sumber daya manusia sangat dipengaruhi etos kerja. Etos kerja diartikan sebagai sikap yang mendasar terhadap diri dan kehidupan di dunia. Motivasi juga mempengaruhi kinerja anggota polisi. Motivasi merupakan faktor yang berpengaruh dalam kinerja anggota polisi. Oleh sebab itu, upaya meningkatkan kinerja organisasi tidak terlepas dari intervensi terhadap motivasi sangat penting dan dianjurkan. Kepuasan kerja juga mempengaruhi kinerja anggota polisi. Kepuasan kerja merupakan 
keadaan emosional baik menyenangkan atau tidak menyenangkan yang dirasakan anggota polisi. Kepuasan kerja mencerminkan perasaan seseorang terhadap pekerjaan.

Anggota polisi dengan motivasi dan kepuasan yang rendah akan memberikan nilai yang negatif baik terhadap individu anggota polisi maupun terhadap organisasi. Pegawai dengan motivasi dan kepuasan rendah tentunya akan memberikan kontribusi rendah terhadap perusahaan. Atas kontribusi yang rendah, maka organisasi akan memiliki outcomes yang sangat kecil, dan dengan outcomes yang sangat kecil, maka organisasi tidak akan dapat memenuhi keinginan dan harapan balas jasa yang layak pada diri anggota polisi. Kompensasi dapat menjamin kepuasan anggota polisi. Organisasi memperoleh, memelihara, dan mempekerjakan sejumlah orang yang memiliki sikap dan perilaku positif bekerja dengan produktif untuk kepentingan organisasi dilakukan dengan memberikan kompensasi yang memadai. Oleh karena itu pengaruhnya dalam memotivasi menjadi sangat kecil, bila mana sekedar dihubungkan dengan pekerjaan rutin sehari-hari, yang biasanya telah dan tetap dikerjakan meskipun tidak diberi insentif (ganjaran).

Kompensasi efektif jika dapat memotivasi karyawan dan meningkatkan produktivitas kerja. Kompensasi diberikan berdasarkan senioritas atau jam kerja. Seseorang bekerja memberikan waktu dan tenaganya kepada organisasi dan sebagai kontra prestasi, organisasi memberikan imbalan atau kompensasi yang bentuknya dapat sangat bervariasi. Sistem yang dipergunakan organisasi dalam memberikan imbalan tersebut dapat memengaruhi motivasi kerja. Berdasarkan hasil studi pendahuluan, diketahui hasil tentang etos kerja, motivasi kerja, kepuasan kerja, dan kompensasi serta kinerja polisi Bidokkes Polda Kalimantan Selatan (Kalsel) ditunjukkan melalui tabel sebagai berikut :

Tabel 1. Hasil Studi Pendahuluan Etos Kerja, Motivasi Kerja, Kepuasan Kerja, dan Kompensasi Biddokes Polda Kalsel Tahun 2017

\begin{tabular}{|c|c|c|c|c|c|c|}
\hline No. & Variabel & Aspek & Rendah & Sedang & Tinggi & $\begin{array}{l}\text { Sangat } \\
\text { Tinggi }\end{array}$ \\
\hline \multirow[t]{4}{*}{1} & Etos Kerja (X1) & 1. Keahlian & - & $15 \%$ & $80 \%$ & $5 \%$ \\
\hline & & Interpersonal & - & $10 \%$ & $90 \%$ & - \\
\hline & & 2. Inisiatif & - & $40 \%$ & $50 \%$ & $10 \%$ \\
\hline & & 3. Dapat diandalkan & - & $20 \%$ & $70 \%$ & $10 \%$ \\
\hline \multirow[t]{8}{*}{2} & Motivasi (X2) & 1. Promosi & - & $10 \%$ & $80 \%$ & $10 \%$ \\
\hline & & 2. Prestasi kerja & - & $10 \%$ & $90 \%$ & - \\
\hline & & 3. Pekerjaan itu sendiri & - & $10 \%$ & $90 \%$ & - \\
\hline & & 4. Penghargaan & & & & \\
\hline & & 5. Pengakuan & - & $10 \%$ & $90 \%$ & - \\
\hline & & 6. Tangguna jawab & - & $30 \%$ & $70 \%$ & - \\
\hline & & 7. Keberhasilan dalam & - & $10 \%$ & $90 \%$ & - \\
\hline & & pekerjaan & - & - & - & $100 \%$ \\
\hline \multirow[t]{7}{*}{3} & Kepuasan kerja (X3) & 1. Kepuasan Gaji & - & $30 \%$ & $70 \%$ & - \\
\hline & & 2. Kepuasan promosi & - & $30 \%$ & $50 \%$ & $20 \%$ \\
\hline & & 3. Kepuasan & - & $30 \%$ & $60 \%$ & $10 \%$ \\
\hline & & Supervisi & & & & \\
\hline & & & - & - & $70 \%$ & $30 \%$ \\
\hline & & 4. Kepuasan rekan & & & & $10 \%$ \\
\hline & & $\begin{array}{l}\text { Kerja } \\
\text { 5. Kepuasan Pekerjaan itu } \\
\text { Sendiri. }\end{array}$ & - & - & $90 \%$ & $10 \%$ \\
\hline \multirow[t]{2}{*}{4} & Kompensasi & 1. Finansial & - & $30 \%$ & $40 \%$ & $20 \%$ \\
\hline & & 2. Nonfinansial & - & $40 \%$ & $60 \%$ & 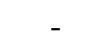 \\
\hline
\end{tabular}

Sumber : Data diolah 
Tabel di atas menggambarkan bahwa etos kerja, motivasi kerja, dan kompensasi masih perlu ditingkatkan karena masih ada persentase kategori sedang. Harapannya adalah minimal etos kerja, motivasi kerja, kepuasan kerja, dan kompensasi mencapai kategori tinggi $100 \%$. Etos kerja, motivasi kerja, kepuasan kerja, dan kompensasi ini berpengaruh terhadap kinerja. Untuk membuktikan pengaruh itu perlu dilakukan penelitian.

\section{Tinjauan Literatur dan Pengembangan Hipotesis Kinerja}

Kinerja adalah hasil dari proses yang mengacu dan diukur selama periode tertentu berdasarkan ketentuan atau kesepakatan yang ditetapkan sebelumnya (Edison et al, 2017: 188). Kinerja adalah kesuksesan seseorang dalam melaksanakan suatu pekerjaan yang dilaksanakannya. kinerja adalah apa yang dapat dikerjakan oleh seseorang sesuai dengan tugas dan fungsinya. Dari batasan-batasan yang ada dapat dirumuskan bahwa kinerja (performance) adalah hasil kerja yang dapat ditampilkan atau penampilan kerja seorang karyawan. Dengan demikian kinerja seorang karyawan dapat diukur dari hasil kerja, hasil tugas, atau hasil kegiatan dalam ukuran waktu tertentu (Notoatmodjo, 2009). Kinerja merupakan suatu hasil yang dicapai oleh pekerja dalam pekerjaannya menurut kriteria tertentu yang berlaku untuk suatu pekerjaan (Robbins, 2008).

\section{Etos Kerja}

Etos kerja merupakan seperangkat sikap atau pandangan mendasar yang dipegang pegawai untuk menilai bekerja sebagai suatu hal yang positif bagi peningkatan kualitas kehidupan, sehingga mempengaruhi perilaku kerjanya dalam organisasi (Priansa, 2014: 283). Etos kerja diartikan sebagai sikap yang mendasar terhadap diri dan dunia ini. Sedangkan kerja secara lebih khusus dapat diartikan sebagai usaha komersial yang menjadi suatu keharusan untuk kelangsungan hidup tersebut, atau sesuatu yang imperatif dari diri, maupun sesuatu yang terkait pada identitas diri yang bersifat sakral.

\section{Motivasi}

Pengertian motivasi dikemukakan para ahli yang isinya hampir sama. Cascio dalam Sunyoto (2012) menyebutkan bahwa motivasi adalah suatu kekuatan yang dihasilkan dari keinginan seseorang untuk memuaskan kebutuhannya, misal; rasa lapar, haus, dan dahaga. Pengertian motivasi seperti yang dirumuskan oleh Terry adalah keinginan yang terdapat pada diri seseorang individu yang mendorongnya untuk melakukan perbuatan-perbuatan (perilaku). (Notoatmodjo, 2009). Sedangkan Stooner mendefinisikan bahwa motivasi adalah sesuatu hal yang menyebabkan dan yang medukung tindakan atau perilaku seseorang (Notoatmodjo, 2009). Flippo dalam Notoatmodjo, (2009) merumuskan bahwa motivasi adalah suatu arahan anggota polisi dalam suatu organisasinya agar mau bekerja sama dalam mencapai keberhasilan organisasi. Motivasi erat berhubungan dengan kebutuhan. Kebutuhan manusia tersusun dalam suatu hierarki dari kebutuhan yang paling dasar sampai kebutuhan yang kompleks. Keinginan untuk memenuhi kebutuhan dapat mempengaruhi perilaku seseorang, dimana hanya kebutuhan yang belum terpuaskan yang dapat menggerakkan perilaku. Kebutuhan yang telah terpuaskan tidak dapat berfungsi sebagai motivasi. Kebutuhan yang lebih tinggi berfungsi sebagai motivator jika kebutuhan yang hierarkinya lebih rendah paling tidak boleh terpuaskan secara minimal. 


\section{Kepuasan Kerja}

Kepuasan kerja adalah keadaan di mana seorang pekerja merasa bangga, senang, diperlakukan adil, diakui, diperhatikan oleh atasan, dihargai, merasa aman karena pekerjaan dapat menghasilkan sesuatu yang memenuhi kebutuhan, keinginan, harapan dan ambisi pribadinya sehingga karyawan merasa puas lahir batin (Noor, 2013). Kepuasan kerja bukanlah hal yang sederhana karena "kepuasan" mempunyai konotasi yang beraneka ragam. Kepuasan kerja merupakan suatu cara pandang seseorang baik yang bersifat positif maupun yang bersifat negatif tentang pekerjaannya (Siagian, 2008).

\section{Kompensasi}

Kompensasi mengandung arti yang lebih luas dari pada upah atau gaji. Upah atau gaji lebih menekankan pada balas jasa yang bersifat finansial, sedangkan kompensasi mencakup balas jasa finansial maupun non-finansial. Kompensasi merupakan pemberian balas jasa, baik secara berlangsung berupa uang (finansial) maupun tidak langsung berupa penghargaan (nonfinansial) (Samsuddin, 2006). Kompensasi adalah segala sesuatu yang diterima oleh karyawan sebagai balas jasa untuk kerja atau pengabdian mereka. Masalah kompensasi merupakan hal yang sangat kompleks, namun paling penting bagi karyawan maupun organisasi itu sendiri. Pemberian kompensasi kepada karyawan harus mempunyai dasar yang logis dan rasional (Notoadmodjo, 2009). Kompensasi merupakan imbalan atau balas jasa yang diberikan oleh perusahaan kepada karyawannya yang dapat dinilai dengan uang. Kompensasi atau imbalan ini termasuk di dalamnya upah, gaji, insentif, komisi, dan sebagainya yang mengikat karyawan sehingga karyawan mau dan senang bekerja. Kompensasi ini harus menarik dan dapat menimbulkan keterikatan karyawan terhadap perusahaan, harus adil, harus dinamis, tidak kaku, harus dapat ditinjau kembali sesuai dengan prestasi karyawan (Alma, 2008).

\section{Kerangka Konseptual Penelitian}

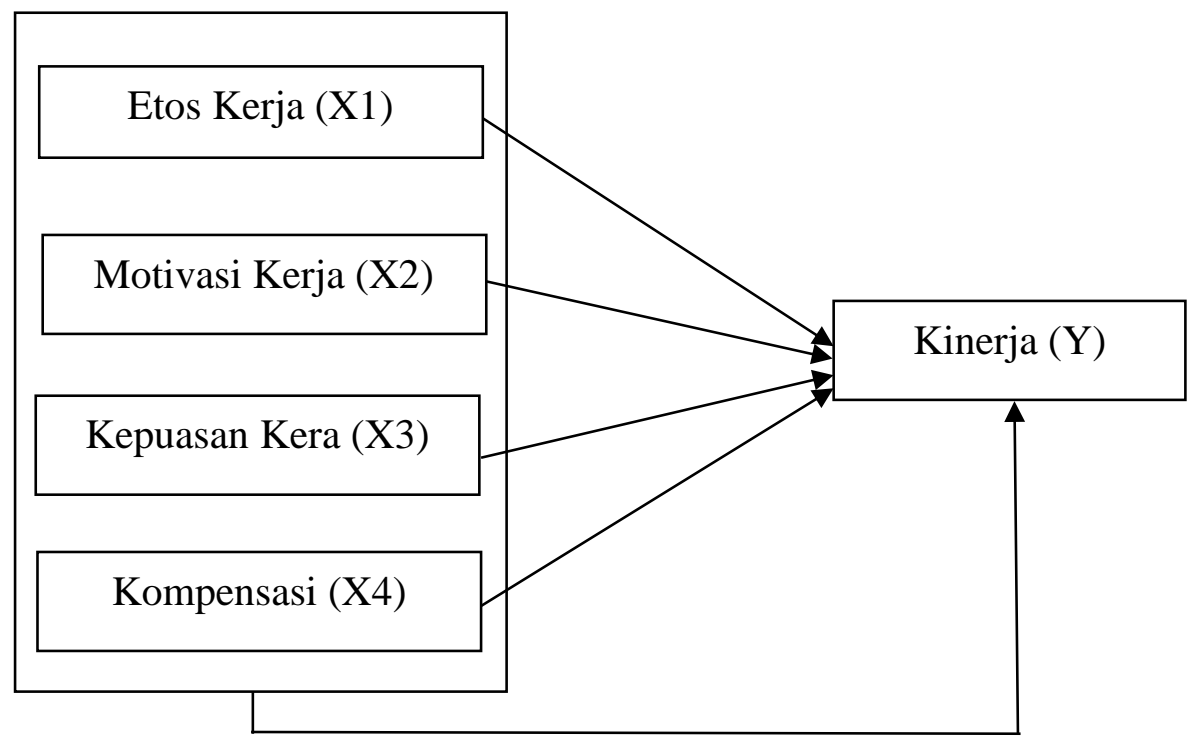

Gambar 1. Kerangka Konseptual Penelitian 


\section{Hipotesis Penelitian}

Berdasarkan kerangka teori dan kerangka konseptual di atas, dirumuskan hipotesis penelitian sebagai berikut.

1. Etos kerja, motivasi kerja, kepuasan kerja, dan kompensasi berpengaruh simultan terhadap kinerja Polisi Biddokkes Polda Kalsel secara simultan.

2. Etos kerja, motivasi kerja, kepuasan kerja, dan kompensasi berpengaruh terhadap kinerja Polisi Biddokkes Polda Kalsel secara parsial.

\section{Metodologi Penelitian}

Uji Validitas

Instrumen yang valid berarti instrument tersebut dapat digunakan untuk mengukur apa yang ingin diukur. Untuk mengukur validitas instrument digunakan rumus korelasi product moment. Nilai $\mathrm{r}$ hitung $>\mathrm{r}$ tabel, maka item dalam angket valid (Nugroho, 2005). Analisis validitas ini dilakukan dengan aplikasi SPSS versi 21 . Hasil uji validitas untuk angket variabel etos kerja, motivasi kerja, kepuasan kerja, kompensasi, dan kinera terlihat pada tabel 1 berikut

Tabel 2. Hasil Uji Validitas

\begin{tabular}{lcccc}
\hline \multicolumn{1}{c}{ Variabel } & Item & r Hitung & r Tabel & Keterangan \\
\hline Etos Kerja (X1) & 9 & $0.460-0.651$ & 0.444 & Valid \\
Motivasi Kerja (X2) & 14 & $0.538-0.659$ & 0.444 & Valid \\
Kepuasan Kerja (X3) & 9 & $0.431-0.649$ & 0.444 & Valid \\
Kompensasi (X4) & 6 & $0.525-0.637$ & 0.444 & Valid \\
Kinerja (Y) & 8 & $0.474-0.678$ & 0.444 & Valid \\
\hline
\end{tabular}

Sumber : Data diolah tahun 2020

\section{Uji Reliabilitas}

Perhitungan reliabilitas dilakukan pada instrumen yang sudah memiliki validitas indeks keandalannya dihitung dengan menggunakan koefisien Cronbach alpha minimal 0.6. Hasil uji reliabilitas dari intrumen/angket penelitian untuk masing-masing variabel, terlihat pada tabel 2 berikut

Tabel 3. Hasil Uji Reliabilitas

\begin{tabular}{llcc}
\hline \multicolumn{1}{c}{ Variabel } & Kriteria & $\begin{array}{c}\text { Cronbach' } \\
\text { s Alpha }\end{array}$ & $\begin{array}{c}\text { Hasil Uji } \\
\text { Reliabilitas }\end{array}$ \\
\hline Kinerja & Cronbach's Alpha $>0.6$ & 0.842 & Reliabel \\
\hline Kompensasi & Cronbach's Alpha $>0.6$ & 0.815 & Reliabel \\
\hline Kepuasan & Cronbach's Alpha $>0.6$ & 0.846 & Reliabel \\
\hline Motivasi & Cronbach's Alpha $>0.6$ & 0.902 & Reliabel \\
\hline Etos Kerja & Cronbach's Alpha $>0.6$ & 0.835 & Reliabel \\
\hline
\end{tabular}

Sumber: Data diolah tahun 2020

\section{Teknik Analisis Data}

Analisis data penelitian ini dikemukakan Analisis deskripsi digunakan untuk mendeskripsikan katakteristik sampel penelitian yang diuji, Uji ini dilakukan melalui beberapa uji yaitu UJi Normalitas bertujuan untuk mengetahui apakah data yang terkumpul 
berdistribusi normal atau tidak, multikolinieritas digunakan untuk mengetahui ada atau tidak variabel independen yang memiliki kemiripan dengan variabel independen yang lain dalam satu model, Uji heteroskedastisitas menggunakan diagram pancar. Kriteria pengujian gejala heteroskedastisitas jika titik-titik pada diagram menyebar tidak beraturan maka terlepas dari gejala heteroskedastisitas.

Analisis regresi ganda adalah suatu alat analisis peramalan nilai pengaruh dua variabel atau bebas atau lebih terhadap variabel terikat untuk membuktikan ada atau tidaknya hubungan fungsi atau kausal antara dua variabel bebas atau lebih dengan satu variabel terikat. Analisis regresi berganda merupakan perluasan dari regersi sederhana yaitu dengan menambah jumlah variabel bebas (regresi berganda) (Sanusi, 2012: 134). Uji regresi ganda dengan menggunakan persamaan garis regresi ganda sebagai berikut.

$$
\begin{aligned}
& \mathrm{X} 1=\text { etos kerja } \\
& \mathrm{X} 2=\text { motivasi kerja } \\
& \mathrm{X} 3=\text { kepuasan kerja } \\
& \mathrm{X} 4=\text { kompensasi }
\end{aligned}
$$

Uji Hipotesis melalui uji F Uji pengaruh simultan dan ketepatan model menggunakan uji $\mathrm{F}$ dan nilai $\rho \leq 0,05$. Jika $\mathrm{F}$ hitung $>\mathrm{F}$ tabel dan nilai nilai $\rho \leq 0,05$, maka hipotesis yang menyebutkan variabel bebas berpengaruh secara simultan diterima dan model penelitian yang diformulasikan sudah tepat dan uji $\mathrm{t}$ Kriteria yang digunakan adalah jika $\mathrm{t}$ hitung $>\mathrm{t}$ tabel dan signifikansi $<0,05$, maka hipotesis diterima

\section{Hasil dan Pembahasan}

\section{Hasil Uji Asumsi}

Normalitas data dapat diketahui melalui diagram P-P Plot regresi. Jika titik-titik mengikuti garis regresi, maka data dinyatakan berdistribusi normal. Hasil analisis regresi P-P Plot penelitian ini menunjukkan titik-titik mengikuti garis lurus sehingga data penelitian ini berdistribusi normal seperti gambar di bawah ini.

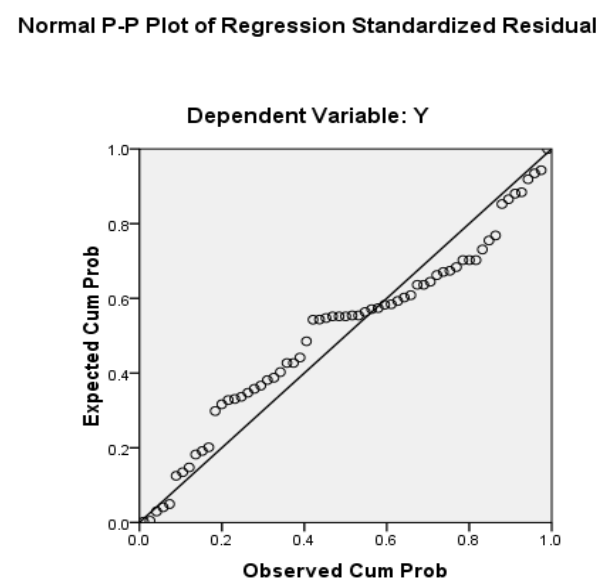

Gambar 2. Normalitas P-P Plot 


\section{Hasil Uji Multikolineritas}

Hasil uji multikolinieritas digunakan untuk mengetahui variabel independen yang satu memiliki kemiripan dengan variabel independen yang lain. Hasil uji multikolineritas ditunjukan pada tabel berikut :

Tabel 4. Hasil Uji Multikolinieritas

\begin{tabular}{clrr}
\hline \multirow{2}{*}{ No. } & \multicolumn{2}{c}{ Variabel } & \multicolumn{2}{c}{ Collinearity Statistics } \\
\cline { 3 - 4 } & & Tolerance & VIF \\
\hline 1. & Etos kerja $(\mathrm{X} 1)$ & 0,302 & 3,311 \\
\hline 2. & Motivasi $(\mathrm{X} 2)$ & 0,273 & 3,669 \\
\hline 3. & Kepuasan Kerja (X3) & 0,391 & 2,558 \\
\hline 4. & Kompensasi (X4) & 0,648 & 1,544 \\
\hline
\end{tabular}

Sumber : Data diolah tahun 2020

Hasil Uji F (Pengaruh Simultan)

Hasil Uji F Pengaruh Simultan ditunjukan pada tabel berikut :

Tabel 5. Hasil Uji F (Pengaruh Simultan)

\begin{tabular}{cc}
\hline Nilai F Hitung & 68,059 \\
\hline Nilai F tabel & \\
\hline Df1 & 4 \\
\hline Df2 & 58 \\
\hline Signifikansi Hitung & 0,00 \\
\hline Signifikansi Kritis & 0,05
\end{tabular}

Sumber : Data diolah tahun 2020

Tabel 5 menunjukkan bahwa nilai $\mathrm{F}$ hitung sebesar 68,059> F tabel $(2,67)$. Nilai signifikansi $0,00<0,05$. Ini berarti bahwa model penelitian ini layak dan hipotesis yang menyatakan etos kerja, motivasi, kepuasan, dan kompensasi dan berpengaruh terhadap kinerja polisi Biddokkes Polda Kalsel secara simultan diterima.

Hasil Uji t (Pengaruh Parsial)

Hasil Uji F Pengaruh Simultan ditunjukan pada tabel berikut :

Tabel 6. Hasil Uji t Pengaruh Parsial

\begin{tabular}{lcccc}
\hline Pengaruh Parsial & $\begin{array}{c}\text { Korfisien } \\
\text { Regresi }\end{array}$ & t hitung & Signifikansi & Keterangan \\
\hline Pengaruh X1 terhadap Y & -0.267 & -4.825 & 0.000 & $\begin{array}{c}\text { Berpengaruh } \\
\text { Signifikan }\end{array}$ \\
\hline Pengaruh X2 terhadap Y & 0.219 & 5.632 & 0.000 & $\begin{array}{c}\text { Berpengaruh } \\
\text { Signifikan }\end{array}$ \\
\hline Pengaruh X3 terhadap Y & 0.402 & 7.421 & 0.000 & $\begin{array}{c}\text { Berpengaruh } \\
\text { Signifikan }\end{array}$ \\
\hline Pengaruh X4 terhadap Y & 0.191 & 2.130 & 0.037 & $\begin{array}{c}\text { Berpengaruh } \\
\text { Signifikan }\end{array}$ \\
\hline
\end{tabular}

Sumber : Data diolah tahun 2020 
Tabel 5 adalah hasil uji $\mathrm{t}$ di atas menunjukkan pengaruh setiap variabel bebas terhadap variabel terikat secara parsial. Kriteria yang digunakan adalah jika nilai signifikansi $<0,05$, maka hipotesis pengaruh parsial diterima. Nilai signifkansi pengaruh etos kerja (X1) terhadap kinerja $(\mathrm{Y})$ 0,00<0,05. Nilai signifikan pengaruh motivasi kerja (X2) terhadap kinerja (Y) $0,000<0,05$. Nilai signifikansi pengaruh kepuasan kerja (X3) terhadap kinerja (Y) $0,00<0,00$. Nilai signifikansi pengaruh kompensasi $0,037<0,00$. Jadi dapat disimpulkan bahwa hipotesis yang menyatakan etos kerja (X1), motivasi kerja (X2), kepuasan kerja (X3), dan kompensasi (X4) berpengaruh signifikan terhadap kinerja (Y) polisi biddokkes Polda Kalsel diterima.

Polisi Biddokkes Polda Kalsel memiliki etos kerja yang tinggi khususnya pada aspek loyal dengan pekerjaan sebagai anggota polisi. Dengan loyalitas yang tinggi memberikan kontribusi terhadap kinerja Polisi Biddokkes Polda Kalsel. Polisi Biddokkes Polda Kalsel juga memiliki motivasi yang tinggi khususnya dalam bekerja dengan baik untuk kenaikan pangkat. Motivasi untuk mendapatkan kenaikan pangkat ini memberikan dampak pada kinerja Polisi Biddokkes Polda Kalsel. Polisi Biddokkes Polda Kalsel memiliki kepuasan yang tinggi khususnya puas dengan pekerjaan, puas dengan pekerjaan karena dapat berbagi pendapat dalam bekerja dengan rekan kerja, puas dengan pekerjaan karena menambah keterampilan. Kepuasan anggota polisi ini memberikan dampaak pada peningkaatan kinerja. Polisi Biddokkes Polda kalsel puas dengan gaji yang diberikan sesuai dengan yang diberikan dan bonus yang diberikan sesuai dengan prestasi kerja. Kepuasan pada aspek pemberian gaji dan bonus ini menjadi faktor yang mendorong terjadinya peningkatan kinerja.

Kinerja sumber daya manusia juga sangat dipengaruhi etos kerja. Etos kerja diartikan sebagai sikap yang mendasar terhadap diri dan kehidupan di dunia. Sedangkan kerja secara lebih khusus dapat diartikan sebagai usaha komersial yang menjadi suatu keharusan demi hidup, atau sesuatu yang imperatif dari diri, maupun sesuatu yang terkait pada identitas diri yang bersifat sakral. Identitas diri yang terkandung dalam hal ini adalah sesuatu yang telah diberikan oleh tuntutan agama. Etos kerja merupakan pandangan dan sikap suatu bangsa atau umat terhadap kerja. Etos kerja menggambarkan suatu pandangan dan sikap, maka dapat dijelaskan bahwa etos kerja mengandung makna sebagai aspek evaluatif yang dimiliki oleh individu (kelompok) dalam memberikan penilaian terhadap kegiatan kerja. Mengingat kandungan yang ada dalam pengertian etos kerja adalah unsur penilaian, maka secara garis besar dalam penilaian dapat digolongkan menjadi dua, yaitu penilaian positif dan negatif. Etos kerja sebenarnya sama dengan istiah semangat kerja atau selera kerja. Anggota polisi yang memiliki etos kerja tentunya menunjukkan semangat untuk berkolaborasi, berdebat, berkomunikasi, dan berprestasi sehingga memberikan kontribusi terhadap kemajuan organisasi (Moehariono, 2012).

Motivasi juga mempengaruhi kinerja anggota polisi. Motivasi merupakan faktor yang berpengaruh dalam kinerja anggota polisi. Oleh sebab itu, upaya meningkatkan kinerja organisasi tidak terlepas dari intervensi terhadap motivasi sangat penting dan dianjurkan (Notoatmodjo, 2014). Kepuasan kerja juga mempengaruhi kinerja anggota polisi. Kepuasan kerja merupakan keadaan emosional baik menyenangkan atau tidak menyenangkan yang dirasakan anggota polisi. Kepuasan kerja mencerminkan perasaan seseorang terhadap pekerjaan. Hal ini dapat dilihat pada sikap positif karyawan terhadap pekerjaan dan sesuatu yang dihadapi di lingkungan kerja. Seseorang merasa "puas" dalam pekerjaan karena apa yang dicapai sudah maksimal. Dalam situasi demikian anggota polisi berprestasi sebaik mungkin (Siagian, 2008). 
Anggota polisi dengan motivasi dan kepuasan yang rendah akan memberikan nilai yang negatif baik terhadap individu anggota polisi maupun terhadap organisasi. Pegawai dengan motivasi dan kepuasan rendah tentunya akan memberikan kontribusi rendah terhadap perusahaan. Atas kontribusi yang rendah, maka organisasi akan memiliki outcomes yang sangat kecil, dan dengan outcomes yang sangat kecil, maka organisasi tidak akan dapat memenuhi keinginan dan harapan balas jasa yang layak pada diri anggota polisi (Triton, 2009). Kompensasi dapat menjamin kepuasan anggota polisi. Organisasi memperoleh, memelihara, dan mempekerjakan sejumlah orang yang memiliki sikap dan perilaku positif bekerja dengan produktif untuk kepentingan organisasi dilakukan dengan memberikan kompensasi yang memadai (Siagian, 2008:). Pemberian ganjaran pada pekerjaan rutin, justru berakibat kurang menguntungkan, karena dapat berakibat pekerja memiliki ketergantungan dalam melaksanakan tugas-tugasnya, yang cenderung diabaikan jika tidak diberikan insentif.

Hasil penelitian ini sejalan dengan studi Husni (2014) yang melakukan penelitian bahwa etos kerja memiliki pengaruh terhadap kinerja. Hal ini menunjukkan bahwa salah satu faktor yang menentukan kinerja tersebut adalah etos kerja yang tinggi. Lebih lanjut, studi Ibrahim (2015) juga mengungkap bahwa motivasi, komitmen, dan insentif adalah faktor yang berperan mempengaruhi kinerja. Sementara itu, penelitian Dizgah, et al. (2012) menjelaskan bahwa terdapat hubungan yang berarti antara kepuasan kerja dan kinerja pada organisasi sektor publik.

\section{Simpulan}

Hasil analisis dan pembahasan memberikan gambaran etos kerja, motivasi, kepusan, dan kompensasi terhadap kinerja polisi Biddokkes Polda Kalsel. Hasil penelitian membuktikan adanya pengaruh etos kerja, motivasi, kepusan, dan kompensasi terhadap kinerja polisi Biddokkes Polda Kalsel. Dengan demikian dapat disimpulkan bahwa 1) Etos kerja, motivasi, kepusan, kompensasi, dan kinerja polisi Biddokkes Polda Kalsel mencapai kategori baik. 2) Etos kerja, motivasi, kepusan, dan kompensasi berpengaruh signifikan terhadap kinerja polisi Biddokkes Polda Kalsel secara simultan. 3) Etos kerja, motivasi, kepusan, dan kompensasi berpengaruh signifikan terhadap kinerja polisi Biddokkes Polda Kalsel secara parsial. 4) Kepuasan kerja berpengaruh dominan terhadap kinerja polisi Biddokkes Polda Kalsel.

\section{Ucapan Terima Kasih (Acknowledgement)}

Ucapan terima kasih kepada Pimpinan Bidokkes Provinsi Kalimantan Selatan. Teristimewa untuk almamater tercinta Universitas Merdeka Malang beserta pembimbing dan seluruh dosen yang sudah memberikan ilmu dan bimbingan selama mengikuti studi lanjut. Juga terima kasih untuk isteri dan anak tercinta yang memberikan doa dan dukungan untuk keberhasilan penulis. 


\section{Referensi}

Alma, Buchari .2008. Pengantar Bisnis. Bandung: Alfabeta

Dizgah, et al. 2012. Relationship between Job Satisfaction and Employee Job Performance in Guilan Public Sector Jurnal. Diakses dari Journal of Basic and Applied Scientific Research www.textroad.com.

Edison, Emron, Yohny Anwar, dan Imas Komariyah. 2017. Manajemen Sumber Daya Manusia. Bandung: Alfabeta.

Husni, Irda. 2014. Hubungan Etos Kerja Dengan Kinerja Guru di SMK Negeri 1 Lubuk Sikaping. Jurnal Bahana Manajemen Pendidikan. Volume 2, Nomor 1, Juni.

Ibrahim. 2015. Impact of Motivation on Employee Performance The Case of Some Selected Micro Finance Companies in Ghana. Jurnal. Diakses dari International Journal of Economics, Commerce and Management United Kingdom

Moeheriono. 2012. Pengukuran Kinerja. Jakarta : PT RajaGrafindo Persada.

Noor, Juliansyah. 2013. Penelitian Ilmu Manajemen Tinjauan Filosofis dan Praktis. Jakarta: Kencana Prenada Media Grup.

Nugroho, B. A. 2005. Strategi memilih Statistik Penelitian dengan SPSS. Yogyakarta: ANDI.

Notoatmodjo, Soekidjo. 2009. Pengembangan Sumber Daya Manusia. Jakarta: PT Rineka Cipta.

Priansa, Donni Juni. 2014. Perencanaan dan Pengembangan Sumber Daya Manusia. Bandung: Alfabeta.

Robbins, S. 2008.Perilaku Organisasi. Jakarta: Salemba Empat.

Samsuddin, Sadili. 2006. Manajemen Sumber Daya Manusia.Cetakan Pertama. Bandung : Pustaka Setia

Sanusi, Anwar. 2012. Metodologi Penelitian Bisnis. Jakarta: Salemba Empat.

Siagian, Sondang P. 2008. Manajemen Sumber Daya Manusia. Jakarta: PT Bumi Aksara.

Sunyoto, Danang. 2012. Manajemen Sumber Daya Manusia. Yogyakarta: CAPS

Triton. 2009. Mengelola Sumber Daya Manusia. Yogyakarta: Oryza. 